Jusmal llmial

PEUR AA DE

Vol. 5, No. 2, May 2017

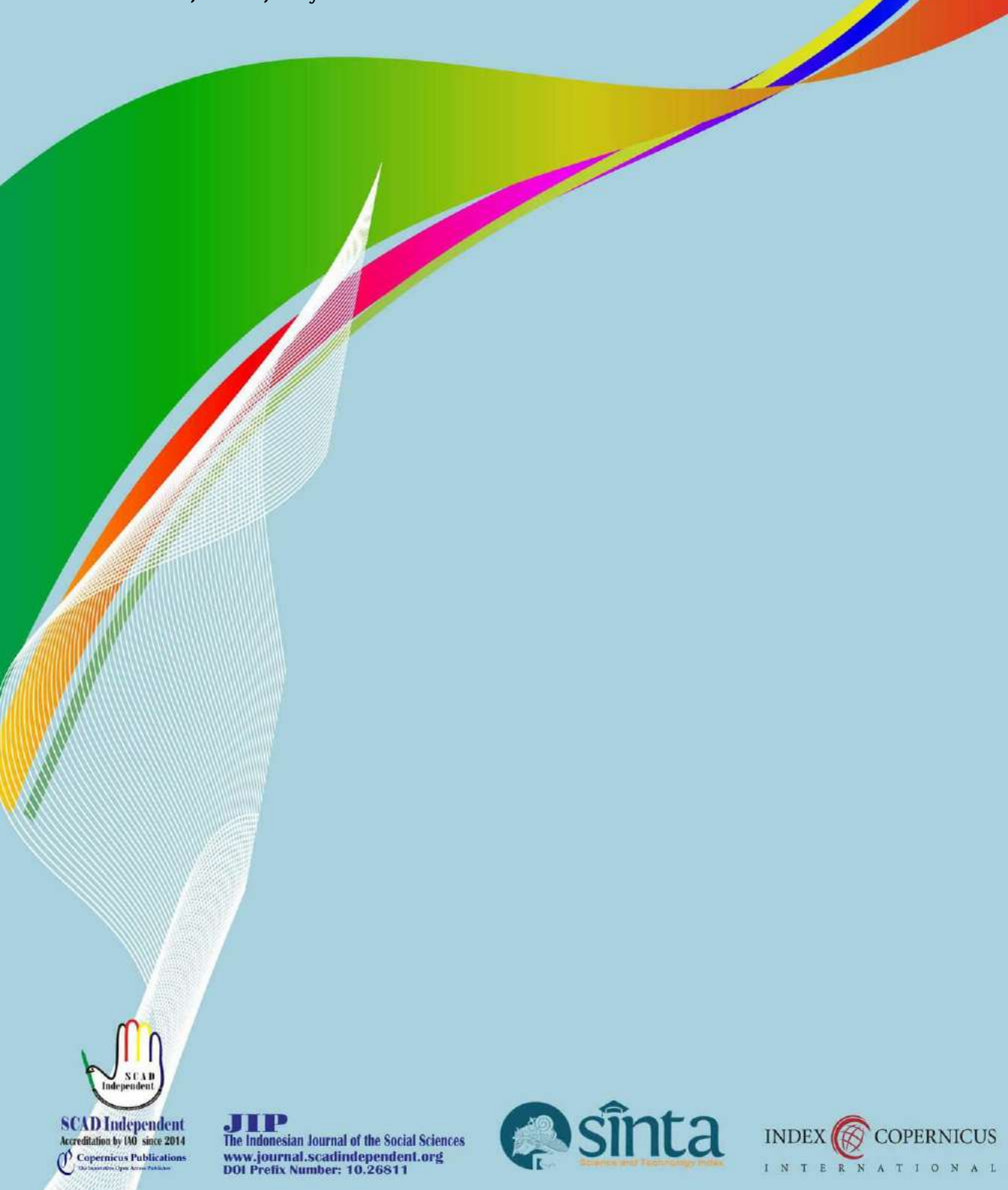


Copyright ( $) 2017$ SCAD Independent

All Rights Reserved

Printed in Indonesia
Jurnal Ilmiah Peuradeun Vol. 5, No. 2, May 2017 Page: $189-200$

\title{
THE INTERNALIZATION OF LOCAL WISDOM VALUE IN DAYAH EDUCATIONAL INSTITUTION
}

\author{
Abdul Hadi \\ Postgraduate Student of UIN Ar-Raniry, Indonesia \\ Contibutor Email: abdulhadiys@gmail.com
}

Received: Dec 15, 2016

Accepted: April 21, 2017

Published: May 27, 2017

Article Url: http://journal.scadindependent.org/index.php/jipeuradeun/article/view/128

\begin{abstract}
This research paper investigates: (1) the educational values in local wisdom tradition (2), the internalization strategy of local wisdom values in educational interaction and (3) the implication of the internalization of Acehnese local wisdom in educational interaction in Dayah on students' behaviour. This qualitative study chose three dayah in Aceh as the sample, they were: Dayah Bustanul Huda (East Aceh), Dayah Mudi Mesra Samalanga (Bireun), and Dayah Darusslam Labuhan Haji (South Aceh). Accordingly, the findings revealed firstly there are three major of educational values in Acehnese local wisdom in Dayah interaction, namely ta'abbudi (worship) value, akhlaqi (moral) value, and the last one is tabarruqi (seek for Allah's blessing by doing benevolence) value. Secondly, the strategies used in the internalization of local wisdom values are (1) traditional strategy, (2) free strategy, (3) reflective strategy and (4) trans internal strategy. And the last is the implication of those values on the students' behaviour, those are; sincerity attitude, ta'zim (honor) to teacher, togetherness, modesty, creativity, tolerance, self-reliance, discipline and mutual respect.
\end{abstract}

Keywords:Interaction, Educational, Values Internalization, Local Wisdom 


\section{A. Introduction}

Interaction is always related to communication or relationship terms. In communication process, they are communicant and communicator. The relationship between communicant and communicator are formed because of communicating something that is called as message. To pass a message, the media is needed. Therefore, there are several elements that involved in communication; they are communicant, communicator, message and media. The same elements also needed in the relationship between human being.

Living environment is one of element that must be delivered in educational interaction in educational institution. Environment provides stimulus to someone and the person responds it back to the environment. Environment as teaching basis is conditional factor that influence individual behavior. It is also an important learning factor. (Oemar Hamalik, 2007: 196).

One of environment-based educational materials is local wisdom. In Acehnese's scope, local wisdom value-based education is protected by law - legislation on Aceh specific privilege (UU No. 44 : 1999).

The law states that: "Province develop and regulate various types of field and education levels as well as adding local content-education materials that in accordance with Islamic Shari'a".

This regulation indicates that education providers in this province are legalized and protected by the law to hold education with certain specific aspects that is Acehnese local wisdom value-based education which contain Islamic values such as honest, strive, discipline, pious, and peaceful.

In order to realize Acehnese local wisdom value-based education, the first step is introducing Acehnese culture to the learners. The history proof that before legislation on Aceh specific privilege issued, Acehnese local wisdom value-based education has been already exist. It is developed by Dayah (local terms for traditional Islamic educational institution in Aceh) that already exist before sultanate era.

Dayah has been developed in Aceh since the introduction if Islam to Aceh by foreign traders. At that time, the traders along with mubaligh (local terms for the person who deliver Islamic missionary endeavor) from Arab arrived in Sumatra coast for trading and delivering Islamic missionary 
endeavor. To accelerate the deployment process, they established Dayah as transformation media for community (Jurnal Dayah, 2008:16).

Dayah is the only educational institution that really concern with tradition. All of traditions become uniquely local wisdom. Some of them are using local language in daily communication, ta'zim keu gure' (local term for greatly appreciating older people, especially teacher), togetherness, sincere, dalail khairat (religious poetic recitation) every Friday night, barzanji (prophetic poetic) recitation on Prophet Muhammad's birthday every year, muhazarah (religious speech), samadiah (prayer ceremony to the died), $t a^{\prime} z i a h$ (visiting the family of the died), kitab Arab Jawi reading and aqidah (belive) strengthen that based on ahlussunnah wal jamaah believe (the believe of prophet Muhammad's followers). Those all traditions still available until today and become the icon of Acehnese local wisdom value-based educational institution.

Based on preliminary research on Mei 2nd in 2013, researcher found that there have been many activities in Dayah based on the value of Acehnese local wisdom which contain Islamic Shari'a and educational principles. For instance in dalail khairat (religious poetic recitation) there are not only religious poetic recitation every Friday night but also an event to inculcate togetherness and artistry in the students' personality. Those all Acehnese local wisdom that have been mentioned before are available till today, both in new and old Dayah which indicate that Acehnese local wisdom in Dayah are can be inherited well. Those stimulate curiosity of the researcher to find out educational value in some other Acehnese local wisdom, discover the Acehnese local wisdom internalization strategies in educational interaction in Dayah, and the implication of Acehnese local wisdom internalization in educational interaction in Dayah on students' behavior.

\section{B. Method}

This qualitative study took three Dayah in Aceh as the sample, they were: Dayah Bustanul Huda (East Aceh), Dayah Mudi Mesra Samalanga (Bireun), and Dayah Darusslam Labuhan Haji (Southern Aceh). Those three Dayah were chosen because of several considerations. Dayah Bustanul Huda 
was chosen because of the consideration that the Dayah is the representation of eastern part of Aceh Province. Dayah Mudi Mesra Samalanga was chosen based on the consideration that the Dayah is the representation of midle part of Aceh Province because it located in the midle part of Aceh region. So does Dayah Darusslam Labuhan Haji was choosen because of the consideration that the Dayah is the representation of southern part of Aceh Province.

The source of data in this research are from interviewing the Tengku (local terms for Dayah's teacher, whether man or woman), students and the management of those three dayah. They are chosen as the interviewees because they are the people that directly involved in dayah educational interaction. In short, those three dayah elements were chosen in terms of purposive sampling. Moreover, the researcher also selects some alumni, public figure and Dayah Education Development Board of Aceh Province as the stake holder of dayah education. Snowballing was employed in this research. The data analyses were done in three steps, they were: data reduction, presentment and verification.

\section{Research Finding}

This research found that there are three educational values in Acehnese local wisdom tradition in Dayah: first, $t a^{\prime} a b b u d i$ (worship) values, that available in samadiah (prayer ceremony to the died), dalail khairat (religious poetic recitation), zikir barzanji (prophetic poetic), and kenduri maulid (charity event that invite many people, especially orphanage and the have not, to eat together in Prohet Muhammad's birthday celebration ceremony). Second, akhlaqi (moral) values, that contained in hadih maja (anonymous Acehnese wise word), kitab Arab Jawi, nazam (Acehneese poem), and seumaloe (Acehnese taboo). And the third, tabarruqi (seek for Allah's blessing by doing benevolence) values, that is available in peusijuk (watering ceremony) tradition, peujok bak gure' (the ceremony while parents hand in their children to the dayah's teacher), ijazah gure'( the ceremony of giving permission from tengku to students, to practice or implement certain specific knowledge), peuphon kitab (the ceremony of started certain kitab recitation/discussion), peutamat kitab (the ceremony of ended certain kitab 
recitation/discussion), beut bak kubu gure' (pray for the died teacher next to his or her grave).

\section{Discussion}

\section{Educational Values in Acehnese Local Wisdom}

There are three major aspects in Acehnese Local Wisdom, they are: ta'abbudi (worship) values, akhlaqi (moral) values, tabarruqi (seek for Allah's blessing by doing benevolence) values. The first one is : ta' abbudi (worship) values. The terms is derived from Arabics word, Ibadah. That etymologically means obedient, comply, submissive, and humble your self. Qardhawi in As-Siddiqi (1994:2-6) state that "worship is the highest loyalty that arise from heart stings awareness in order to glorify the God". Based on the definition above, the value of worship here is that value of obedience in doing a wide variety of Islamic religious practice to glorify Allah swt.

In Dayah tradition, samadiah (prayer ceremony to the died), recitation is a kind of believer worship to Allah. It is because, in samadiah (prayer ceremony to the died), dayah students recite istighfar (prayer to ask for forgiveness), shalawat (praise recitation for Prophet Muhammad Saw), surat Al-Ikhlas, Al-Falaq, An-Nas (certain part or verses in Alquran), and tahlil (reciting la ilaha illallah that means there is no God but Allah) and pray together at the end of the samadiah (prayer ceremony to the died). The prayer is contain of ask for forgiveness for all of died moslem to be dissociated from the grave punishment and become the occupant of heaven. Lastly, the prayer also intended to ask may Allah Swt. Gives fortitude to the family that leaved by the died.

Second, akhlaqi (moral) values; the word "akhlak" is a plural form of arabic word, khuluq, that means behaviour, character, and manner (Munawir, 1984:393). Etymologycally Gazalba (1971:42) defined that "akhlak" is a spiritual attitude which produce manner, whether related to the moslem themselves, God, and fellow human in accordance with Allah's orders and prohibitions that stated in Alquran and Prophet Muhammad's hadith. Based on the definition above, akhlaqi (moral) values that related to local wisdom context is the well manner behavior arising 
from the implementation of local wisdom that usefull for the Dayah's students which usefully foar their daily activity. The Acehnese local wisdom tradition that contain akhlaqi values are hadih maja (anonymous Acehnese wise word), nazam (Acehneese poem), Arab Jawi recitation, and seumaloe (Acehnese taboo).

The third is tabarruqi (seek for Allah's blessing by doing benevolence) values. "Tabarruk" is derived from Arabic's word: "barakah". Al-Asiry dictionary (Munawir, 1984:393), "barakah" means blessing, grace and blissfulness. Tabarruk meaning is seeking for Allah's blessing by doing benevolence (Al Hamid Al Husaini, 1997:197). Therefore, tabarruqi values in terms of local wisdom means Acehnese local wisdom tradition which implemented in Dayah that intended to achieve Allah's blessing. The tradition that content tabarruqi values are peusijuk (watering caremony) tradition, peujok bak gure' (the ceremony while parents hand in their children to the dayah's teacher), ijazah gure' (the ceremony of giving permission from tengku to students, to practice or implement certain specific knowledge), peuphon kitab (the ceremony of started certain kitab recitation/discussion), peutamat kitab (the ceremony of ended certain kitab recitation/discussion), beut bak kubu gure' (pray for the died teacher next to his or her grave).

\section{The local wisdom internalization strategies in educational interaction in Dayah in Aceh}

Strategy means carefully plan about an activity to achieve specific goal (KBBI, 1999:964). In teaching and learning field, Taufiq (2010:1) defined that strategy is "general patterns of teachers and students in teaching and learning activities in order to achieve the goal which has been set". Internalization literally means profound (KBBI, 1999:384). Value is a characteristic that important for humanity (KBBI, 1999:690). While local wisdom can be defined as righteousness that become tradition as a result of assimilation between religious values and the intelligence of the wise people that has been inherited hereditary. 
Conceptually, Muhaimin (2012:173) propose four strategies in value internalization, there are: traditional, free, and reflective and transitional.

First, value learning using traditional strategies is reached by giving advice or indoctrination. In this strategy, teachers have a great role, especially for new students in Dayah. The new students only practicing certain local wisdom as the teachers' instruction. They also practicing dayah convention rule, for example: samadiah (prayer ceremony to the died), dalail khairat (religious poetic recitation), muhazarah (religious speech), zikir maulid (prayer in prophet Muhammad's birthday celebration), and zikir $b a^{\prime} d a$ shalat (prayer after daily five obligation).

The second is transitional strategies. This strategy is implemented by doing value transformation then continued by transaction and Tran internalization. In this case, both teachers and students are involved in communication process not only verbal and physical, but also inner communication. With this strategy, teachers participate as information presenter, example given, and the source of innate positive value. While the students receiving the information and respond the stimulus physically and try to transfer and pattern them selves to the righteousness value that fit as the teachers' input. This strategy is accordance with the divinity and humanity values (Muhaimin, 2012: 173-174).

Concerning transitional strategy is implemented to the above-third year students. Those students are used to involve in communication with the tengku (teacher). In every kitab discussion, they always hold muzakarah (discussion) and munaqasyah (sharing) with the tengku (teacher), not only in learning session but also after the learning hours they also involved in educational communication. The transformation process is done based on two methods that already mentioned above.

The third is free strategy, value learning using this free strategy is the verse versa of traditional strategy, that means the teacher do not tell the students the good and bad value, but the students are given a right to chose and determine which value that they want to acquire because a good thing from others is not always good for themselves. 
The fourth is reflective strategy ('ibrah). Local wisdom valueimplementation in this strategy, students are emphasizing to develop analyses ability on the local wisdom that they get in daily activity in dayah. This strategy is usually implemented to the dayah advance student.

\section{The implication of Acehnese local wisdom internalization in educational interaction in Dayah on students' behavior}

Implication means involvement (KBBI, 1999:374). Whereas value means the important things in life (KBBI, 1999:690). Thus, implication in this research means students involment in practicing various characters that beneficial to their daily life in dayah. Those various characters are: sincerity, ta'zim (honor) teacher, togetherness, modesty, creativity, tolerance, self-reliance, discipline and mutual respect. Here are the explanation of those all characters.

First, sincerity. Sincerity in means pure-minded (KBBI, 1999:368). This character are internalize in dayah students because since the first time the students are hand in to the teacher by their parents (peujok bak gure'), the teacher remind the students that all of activity in dayah must be done sincerely because of every activity in dayah is a kind of worship and purely to search for religious knowledge.

Second, $t a^{\prime} z i m$ (honor) teacher, that means respect (KBBI, 1999:357). In dayah, each activity of the students are really depend on the tengku (teachers) approval. Dayah students believe that $t^{\prime}{ }^{\prime} z i m$ (honor) teacher is one of the source of blessing.

The third is togetherness. Dayah's life emphasize prioritizing the right of others, while in obligation matter the students are educated to put themselves first. There are many activities in dayah that inculcate this character, such as dalail khairat (religious poetic recitation), zikir barzanji (prophetic poetic), and kenduri maulid (charity event that invite many people, especially orphanage and the poor, to eat together in Prohet Muhammad's birthday celebration ceremony). This activity usually held by every kabilah (students association).

The fourth is modesty. Modesty is one of dayah's students characteristic. They are educated to have simple look, reasonable thinking, proportional, and avoid snobby. There is a Hadih maja (anonymous 
Acehnese wise word) which related to modesty and become a precept in dayah students:

"ta hemat yoh mantong na", (be economical while rich)

"beuteugoh yoh goh celaka", (be carefull before accident)

"jak bak laku lingang, pinggang ban laku ija", (walk as your step, wear a fit sarong)

"ngui ban laku tuboh, pajoh ban laku atra" (get dress that fit to your body, shopping appropiately as the ammount of your money).

The fifth is creativity. Creative means have creativity, have a capacity to create, while creativity means the ability to create (KBBI, 1999:529). Arab Jawi writing is a kind of yore scholars' creativity that be worth to be exemplified of every dayah's student. Some activity that stimulate students creativity are hold bahtsul masail (problem solving), kaligrafi (Arabic art writing), writing opinion, and students cottage design. Hadih maja (anonymous Acehnese wise word) state that:

"meunyo hana tauseuha, panee teuka rhot di manyang"

(without struggle something will not falling down from the sky)

"jaroe bak langai, mata u pasai".

(even hand holding tractor, be visionaire)

"meunyo jeut buet jaroe, u cong duroe pih seulamat",

(creative person will survive even in difficult condition)

"meunyo hanjeut buet jaroe, ata lam peutoe pih kiamat".

(without creativity, even saving, will dissappear)

The Hadih maja (anonymous Acehnese wise word) above have a meaning that closes to the utterance: no finding without digging, no victory without struggling. Furthermore, the Hadih maja (anonymous Acehnese wise word) also explain that without an effort, do not dream the result come up automatically. Creative people will be able to survive in the most difficult situation while without creativity; we just spent the rest of our life to waste our wealth. 
The sixth is tolerance. Tolerance means able to appreciate the feelings of others (KBBI, 1999:1037). One of the representations of this feeling in dayah's life is samadiah (prayer ceremony to died people) recitation. Samadiah (prayer ceremony to the died people) recitation is held to the died people, who ever they are, whether there is some one in dayah or one of the society (member) who live around the dayah. Another form of tolerance (appreciate the feelings of others) in dayah's life is cooking together. The students cook together in soup house and sometimes they give their food voluntarily, to the friends of them who are running out of stock.

The seventh is self-reliance. Self-reliance means a situation that not depending on any other else (KBBI, 1999: 625). Self-reliance is an attitude that someone do not want to bothersome others in any matter. In dayah's life, self-reliance is really visible in students' activity. Everyone is responsible for his or her need. For instance, in Dayah Darusslam Labuhan Haji (Southern Aceh), a student who has just graduated from elementary school and continue his study to dayah, he must wash his own clothes, ironing it, and cook for himself.

The eight is discipline. The discipline value can be seen from the student's obedience toward the dayah's rules. In those three dayah that become the source of data in this research, it found that students have too many activities from wake up until go to bed. All of the activities must be done in certain time or schedule.

The last one is mutual respect. Dayah's students are come from various regions and tribes in Aceh and outside Aceh. Furthermore, a small number of the students are also come from overseas such as Malaysia and Thailand. Each region has students association. Nevertheless, the students still implement the mutual respect attitude to develop a healthy communication and interaction among them.

\section{E. Conclusion}

Based on the research above, it can be conclude that Acehnese local wisdom is one of material in educational interaction process that have important role in fostering students behavior. In the other words, local 
wisdom practicing can influence student's behavior. In dayah local wisdom, it found three major educational values, there are: ta'abbudi (worship) values, akhlaqi (moral) values, tabarruqi (seek for Allah's blessing by doing benevolence) values. Those three values are internalized by four strategies: there are: traditional strategy, transinternal strategy, free strategy and reflective strategy. Lastly, the implication of Acehnese local wisdom internalization in educational interaction in Dayah on students' behavior is resulted nine major attitudes, there are: sincerity, ta'zim (honor) teacher, togetherness, modesty, creativity, tolerance, selfreliance, discipline and mutual respect. Those all of attitudes are reflected in dayah's student's daily life.

\section{Bibliography}

Al Husaini, Al Hamid (1997). Pembahasan Tuntas Perihal Khilafiah, Bandung: Pustaka Hidayah.

Aliy, Atabik dan Mahdhor, Zuhdi, Ahmad (1996). Kamus Al 'Ashriy, Yoygyakarta: Multi Karya Grafika.

Al-Zarnuji (2004). Ta'lìm tārīq al Ta'allum, cet I, Khartoum: al Dar al Saudaniahli al qutub.

AM, Sardiman (2011). Interaksi dan Motivasi Belajar Mengajar. Jakarta: Rajawali Pers.

Badan Pembinaan Pendidikan Dayah Aceh. (2008). Seluk Beluk Dayah di Aceh. Jurnal Dayah, No 1 Tahun I.

Faruqi, Y. M. (2015). Role of Muslim Intellectuals in the Development of Scientific Thought. Jurnal Ilmiah Peuradeun, 3(3), 451-466.

Fatimatuzzahroh, F., Abdoellah, O. S., \& Sunardi, S. (2015). The Potential of Pesantren In Sustainable Rural Development. Jurnal Ilmiah Peuradeun, 3(2), 257-278.

Gazalba, Sidi (1971). Pola Ajaran Agama Islam, Jakarta: Bulan Bintang. 
Hadi, A. (2014). Dinamika Sistem Institusi Pendidikan Di Aceh. Jurnal Ilmiah Peuradeun, 2(3).

Hamalik, Oemar (2007). Proses Belajar Mengajar. Jakarta: Bumi Aksara.

Huwaida, H. (2015). Change and Development in the Acehnese Dayah Salafi (A Case Study). Jurnal Ilmiah Peuradeun, 3(2), 279-294.

Marzuki, M. (2016). Diniyyah in Public Schools: A Model of Islamic Curriculum Implementation in Multi Religious Society in Banda Aceh-Indonesia. Jurnal Ilmiah Peuradeun, 4(1), 15-26.

Mastuhu (1994). Dinamika Sistem Pendidikan Pesantren, Jakarta: INIS.

Muhaimin (2002). Paradigma Pendidikan Islam, Bandung: Rosda.

Munawwir, Warson, Ahmad (1984). Al-Munawwir Kamus Arab-Indonesia. Yogyakarta: Al-Munawwir

Sugiono (2011). Metode Penelitian Pendidikan. Bandung: Al fabeta.

Syahminan, S. (2014). Modernisasi Sistem Pendidikan Islam di Indonesia pada Abad 21. Jurnal Ilmiah Peuradeun, 2(2), 235-260.

Taufik (2010). Strategi Belajar Mengajar, Jakarta: Inti Prima.

Tim Penyusun depertemen Pendidikan dan Kebudayaan. (1999). Kamus Besar Bahasa Indonesia (KBBI). Jakarta:, Balai Pustaka. 